\title{
Perspectives for development of ice-core drilling technology: a discussion
}

\author{
P.G. TALALAY \\ Polar Research Center, Jilin University, Changchun City, China \\ E-mail: ptalalay@yahoo.com
}

\begin{abstract}
More than 170 years ago, Louis Agassiz, one of the creators of glacial theory, made his first attempt to drill into the bed of Unteraargletscher, Swiss Alps. Since that time, various systems for thermal and mechanical drilling have been designed especially for boring into ice, and some conventional drill rigs been adopted for ice coring. Although contemporary ice-drilling knowledge and techniques are now familiar, there remain many problems to be solved by advanced modern technology. Specific challenges related to improving old drilling methods and developing new emerging technologies include: (1) identification of depth limitation of 'dry' drilling; (2) improvement of casing; (3) searching for the new environmentally friendly low-temperature drilling fluids; (4) reliable elimination of sticking drills; (5) improvement of core quality in the brittle zone; (6) additional core sampling from borehole walls after the core has been drilled; (7) obtaining oriented core; (8) designing automation drilling systems; (9) developing rapid-access drills. Possible ways of solving these problems are presented below.
\end{abstract}

KEYWORDS: ice coring, ice engineering, ice rheology

\section{INTRODUCTION TO ICE-DRILLING METHODS}

Drilling operations in the polar and mountain regions are complicated by extremely low surface temperatures and, inboard of glaciers, glacier flow, absence of roads and infrastructure, storm winds, snowfalls, etc. More than 170 years ago, in 1841, Louis Agassiz, one of the creators of glacial theory, made his first attempt to drill into the bed of Unteraargletscher, Swiss Alps (Clarke, 1987). Since then, various icedrilling systems have been designed and tested; many of these have been quite effective but some have proven to be temperamental. In principle, it would be possible to use conventional rotary drilling technology to drill into ice, and early rotary drilling yielded acceptable drilling rates. However, such is the power consumption and the weight of conventional rotary drilling rigs that they remain difficult to use for glacial exploration. For ice drilling, special-purpose drilling equipment and technology have been designed and tested in various institutes throughout the world.

Depending on the nature of the ice disintegration at the borehole bottom, all developed methods of ice drilling can be divided into two systems: mechanical and thermal. Mechanical drilling tools can use percussion or rotary fracturing of ice, but most commonly use cutting. Thermal drills can use electric heaters, hot water, steam or hightemperature gases for ice melting. The specific energy required for thermal drills $\left(590-680 \mathrm{MJ} \mathrm{m}^{-3}\right.$ ) is two orders of magnitude higher than the energy required for mechanical systems (1.9-4.8 MJ m ${ }^{-3}$ ) (Koci and Sonderup, 1990).

There are several other attributes for classification of icedrilling methods. The overall division is based on the possibility of core recovery, and is between full-face (noncore) drilling, which produces only cuttings or melted water, and core drilling, which produces core samples and cuttings (melted water) from the kerf.

Another subdivision suggests utilizing drilling fluid. If ice cuttings or melted water are removed from the borehole by direct lifting (augering, bailing, pumping) or air circulation, this acts, in effect, as 'dry' drilling as the borehole shaft is filled with air. On the other hand, drilling deeper than 300$350 \mathrm{~m}$ shows significant closure in an open hole. The main functions of drilling fluid in this case are to maintain the stability of the borehole and to transport cuttings (or melted water) from the bottom to the downhole chamber or to the surface. Sometimes this method is referred to as 'wet' drilling. In certain circumstances, in order to improve the core quality of 'dry' drilling, small amounts of drilling fluid can be added to the bottom of the hole $(\sim 15 \mathrm{~m}$ of the fluid column) and drilling becomes 'semi-wet'.

Although current ice-core drilling knowledge is high, there are still many problems to be solved by advanced modern technology. Some difficulties such as improving drilling fluids, the core quality of brittle ice, drilling efficiency in the 'warm' ice, and replicating coring methods were identified by participants in the International Partnerships in Ice Core Sciences (IPICS) Workshop in March 2004 (Algonkian Regional Park, Sterling, VA, USA; Wilhelms and others, 2004). Although some new approaches have been developed, problems are still not resolved completely. Moreover, there are specific challenges related to the improvement of old drilling methods as well as to the development of new emerging technologies. Some points regarding the future development of ice-core drilling technology are proposed and discussed below.

\section{DEPTH LIMITATION OF 'DRY' DRILLING}

Currently the depth limitation of 'dry' drilling in ice is under renewed discussion by members of the ice-drilling community. It is generally recognized that drilling in ice without fluid can be carried out safely to depths of 300-350 m, and most cores retrieved from depths greater than 150-180 m have quite poor quality (e.g. Gillet and others, 1984; Schwander and Rufli, 1988). Nevertheless, in order to simplify and speed up intermediate drilling operations, it has 


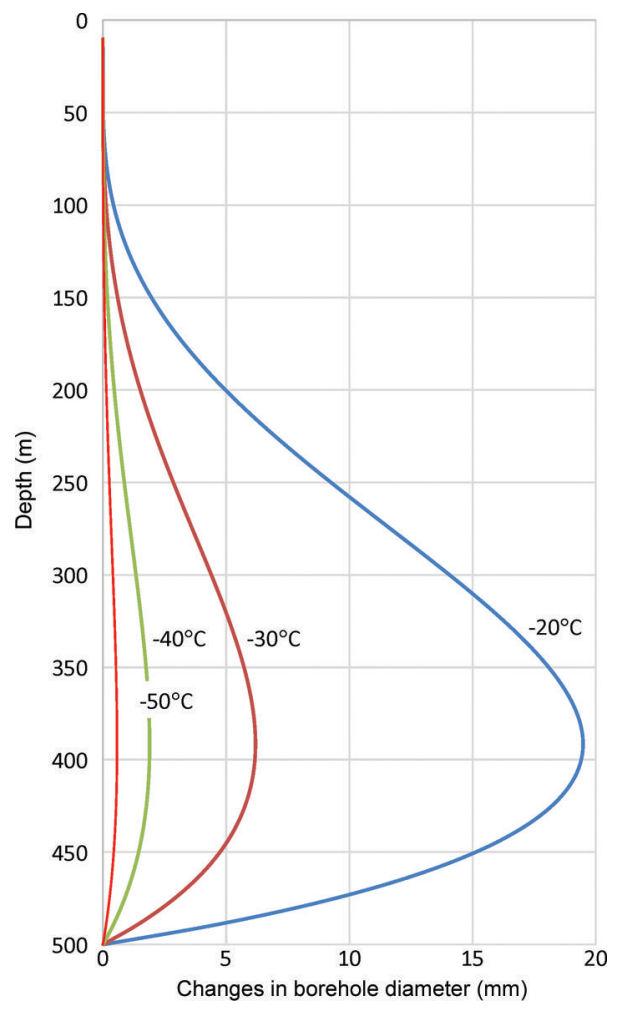

Fig. 1. Diameter changes of $500 \mathrm{~m}$ deep 'dry' borehole vs depth based on the prediction method described by Talalay and Hooke (2007) and Talalay and others (2014b).

recently been considered optimal to drill 'dry' holes down to $500 \mathrm{~m}$ or deeper, although the quality of the core can suffer (e.g. Motoyama and others, 2013). Another 'dry' drilling approach, proposed by the British Antarctic Survey (BAS), is to deploy the new wireline rapid-access isotope drill, which is able to complete a $600 \mathrm{~m}$ drilling cycle in just 1 week, before being redeployed at the next drilling location (Subsea World News, 2014). The drill will collect only ice cuttings, which can be used for isotope analysis and climate profiling, and leave an access hole to allow deployment of a temperature-sensing cable.

In any circumstance, the 'dry' borehole will close because the ice pressure is not compensated by the pressure inside the borehole. Figure 1 shows the borehole closure prediction for four ice-temperature options at $10 \mathrm{~m}$ depth: $-20,-30,-40$ and $-50^{\circ} \mathrm{C}$. The hole's temperature profile is approximated by the linear distribution with a geothermal coefficient of $0.005^{\circ} \mathrm{C} \mathrm{m}^{-1}$. It is assumed that drilling operations are accomplished during one season to the target depth of $500 \mathrm{~m}$ within 26 days. Comparison of the curves suggests that the ice temperature has a profound effect on closure rate. The borehole with a near-surface temperature of $-20^{\circ} \mathrm{C}$ closes very fast, with a top rate of $\sim 7 \mathrm{~mm} \mathrm{~d}^{-1}$ at the bottom of a $500 \mathrm{~m}$ deep hole. The critical depth is $90-110 \mathrm{~m}$ above the target depth where the borehole diameter changes to the maximum extent.

To guarantee a drilling process without drill sticking, the borehole should be drilled not only as fast as possible but also with oversized diameter, and three drilling methods might be considered: (1) section drilling; (2) drilling with intermittent reaming; and (3) reaming while drilling.

Section drilling means that the borehole is drilled in 'stepping down' mode. Once the predetermined depth is reached, a smaller-diameter borehole is continued. Drilling

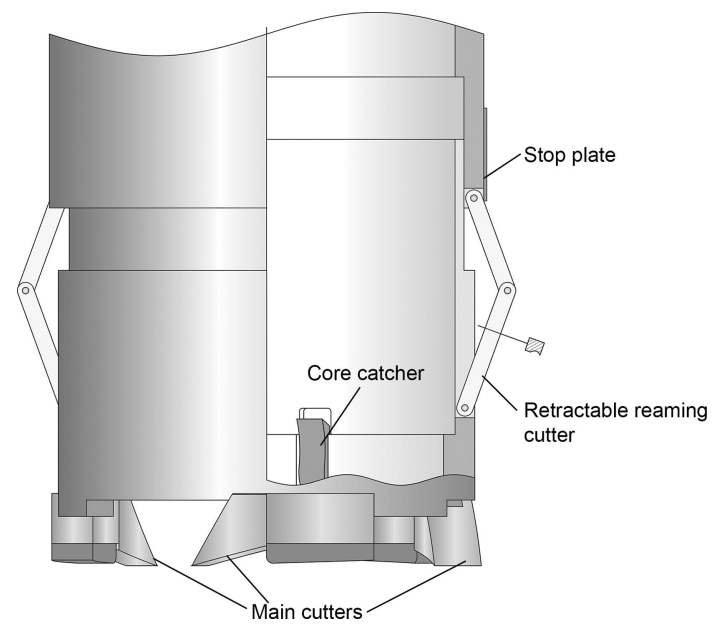

Fig. 2. Drill head for reaming while drilling.

with intermittent reaming includes enlarging the borehole with the special reamer at predefined intervals (e.g. after every $20 \mathrm{~m}$ of drilling). Neither of these methods can prevent drill sticking as, in all circumstances, the hole could close around the drill immediately after penetration due to ice primary creep.

When attempting to overcome the issue of hole closure in a dry hole (which results in a stuck drill), one solution is to ream simultaneously while drilling. For intermediate 'dry' drilling it is suggested that an electromechanical drill with air reverse circulation be used (Talalay and others, 2013). The concept of the drill is similar to deep ice electromechanical drills with fluid circulation, but the air pump (instead of the fluid pump) is used to suck ice cuttings to the chip chamber installed above the core barrel. The air from the pump outlet is ejected into the annular space between the drill and borehole walls forming near-bottom air reverse circulation. As contrasted with ice drills with fluid circulation, air reverse circulation can be readily applicable to the upper permeable snow-firn zone, avoiding problems with casing tightness, circulation loss and drill site pollution.

To optimize hole enlargement while drilling, the drill head contains reaming cutters that are able to be withdrawn into the drill head body during tripping operations (Fig. 2). Reaming cutters are opened when the drill head stands on the hole bottom, and ream the hole jointly with the main cutters. Adjustable stop blades limit the offset of reaming cutters and specify the reaming diameter. All cuttings are picked up by the near-bottom air reverse circulation and collected in the inner chamber.

Another possible low-risk approach to drilling intermediate 'dry' holes is rapid ice-drilling technology with cuttings and cores continually transported by air reverse circulation (Wang and others, 2013). Mechanical drills with air circulation (without cores) are capable of drilling in firn and ice at a rate as high as $180 \mathrm{~m} \mathrm{~h}^{-1}$ (Bentley and others, 2009). Supposing that the rate of penetration with continually transported cuttings and cores would be close to this value and accounting the additional time for making connections, coring of a $500 \mathrm{~m}$ deep hole could be accomplished within 10-12 hours. Compressed air flows through the dual channel swivel, the annular space of double-wall drill pipes and the downhole turbine. Air then enters the grooves of the drill bit and carries out cuttings and the core samples through the center of the drill bit into the 
inner space of the double-wall drill pipe. On the surface, core samples and cuttings are pushed out from the discharge hose and collected in sampling boxes. This method is quite popular in exploration engineering but needs to be modified according to specific conditions of ice sheets (compressed air should be dried and cooled before injection).

\section{CASING}

The important part of borehole planning is the selection of the casing, a hole liner used to isolate the permeable nearsurface snow-firn formation, the thickness of which depends on the accumulation rate and temperature conditions at the drilling site. It is recognized that firn becomes impermeable ice when its density reaches $830 \mathrm{~kg} \mathrm{~m}^{-3}$. In different regions of inland Antarctica and Greenland, the depth of the firn-ice transition varies within the range 64-115m (Cuffey and Paterson, 2010).

The drilling of uncased holes was applied in intermediate drilling projects in Greenland (Hans Tausen in 1995, Flade Isblink in 2006 and NEEM in 2011) (personal communication from J.P. Steffensen, 2014) and Antarctica (James Ross Island in 2008, Fletcher Promontory in 2011/12 and Aurora Basin in 2013/14) (Mulvaney and others, 2014; Sheldon and others, 2014a). Filling with drilling fluid was carried out through a hose lowered into the hole. In our opinion, such technology cannot prevent leaks especially during tripping operations, and in order to reduce drilling fluid consumption and environmental contamination the permeable firn zone should preferably be isolated with a casing. Moreover, the completely tight casing is an essential requirement of recently designed rapid-access ice-drilling technologies for on-the-fly ice coring and subglacial rock coring (e.g. Goodge and Severinghaus, 2014).

In the first stages of deep ice-drilling evolution, a steel casing was used (e.g. within the Greenland Ice Sheet Project at Dye-3; Rand, 1980). This system created several difficulties: rust from the casing penetrated the seals in the drill, which required frequent disassembly and cleaning; the casing was not tight (there were leaks both at the casing bottom and at several connections); and the individual casing tubes were not centered, causing the drill bits to break as the drill passed down through the casing (Johnsen and others, 1994).

In recent times, a special fiberglass or HDPE casing has generally been used within standard procedures of icedrilling technology. Each individual section of this casing is connected with threaded pin and box ends sealed by PTFE tape or unthreaded pin and box ends held together by a steel wire and sealed with an O-ring. Overall, the system has worked well, and the casing may be mounted in 1 or 2 days.

Unfortunately, fiberglass/HDPE casing is also not tight. Problems with leaks both at the casing bottom and in connections that are not well sealed almost always appear while drilling (Talalay and Gundestrup, 2000; Vasiliev and others, 2007; personal communication from J. Johnson, 2014; personal communication from F. Wilhelms, 2014). To avoid possible leaks in connections, the HDPE tubing could be permanently terminated piece-by-piece with a heat fusion welding set as proposed by the SUBGLACIOR project (Duphil and others, 2014). Tests under air pressure, followed by filling with drilling fluid and carried out at Dome C, Antarctica, in summer 2013/14, have shown that casing with welded connections is tight enough.

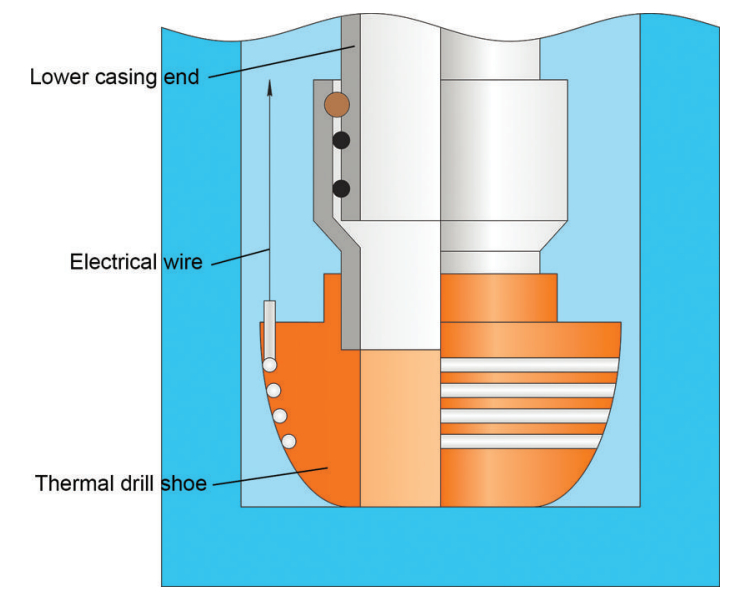

Fig. 3. Thermal casing shoe.

In principle, hot water pumped directly to the bottom of the casing may be a good solution for sealing the annular space if it freezes up without cracks. However, cracks can develop afterwards because of the hydrodynamic pressure of drilling fluid and mechanical impact from the drill string. To seal the casing shoe more carefully, a special thermal head (Fig. 3) was proposed and successfully tested in a 5G deep borehole at Vostok station, Antarctica (Kudryashov and others, 2002). While casing tubes are run into the hole, the electric wires are held fixed on their surface by clamps. When the shoe of the lower casing tube reaches the bottom of the pre-drilled dry hole, the power of the thermal element is switched on and the ice begins to melt. The casing is lowered smoothly and the heating is stopped when the column is lowered into the ice by $0.5-1.0 \mathrm{~m}$. In order to refreeze water around the shoe and to ensure impenetrability of this zone, the casing column was left at rest for some time. Humphrey and Echelmeyer (1990) showed that melted water refreezes very rapidly if the ice temperature is low $\left(<-20^{\circ} \mathrm{C}\right.$; e.g. the borehole filled with water will totally close in $4-23$ hours with an ice temperature of $-25^{\circ} \mathrm{C}$ and initial radius $50-120 \mathrm{~mm}$, respectively). Once the casing is set down, ice-core drilling continues, beginning from the ice inside the casing that can be recovered from the hole. The casing is not retrievable.

To accelerate and simplify casing operations, it is best to use continuous low-temperature PVC tubing: an extruded polyvinylchloride tubing manufactured to withstand temperatures as low as $-70^{\circ} \mathrm{C}$ (e.g. Astra $\odot 601$ PVC lowtemperature tubing (Suflex Inc., 2014)). The plasticized PVC tubing can be easily coiled on the service reel for tubing storage, and on the spooling device during tubing lowering. Once drilling is completed to the required depth, PVC tubing casing is retrieved by spooling it onto the service reel where it can then be repeatedly used in the additional boreholes. The lower end of PVC tubing is not sealed, so this method can be used only for protecting the snow-firn zone from pollution while the hole is filled with drilling fluid and during tripping operations.

Another method to avoid casing installation and to prevent drilling fluid loss is to use an independent noncored hot-point drill - an electrically heated probe that melts a full-diameter hole - to drill the upper snow-firn layer (Fig. 4). During drilling, porous formations are saturated with melted water, which eventually consolidates into ice lining. Water surplus is pumped out to the surface 


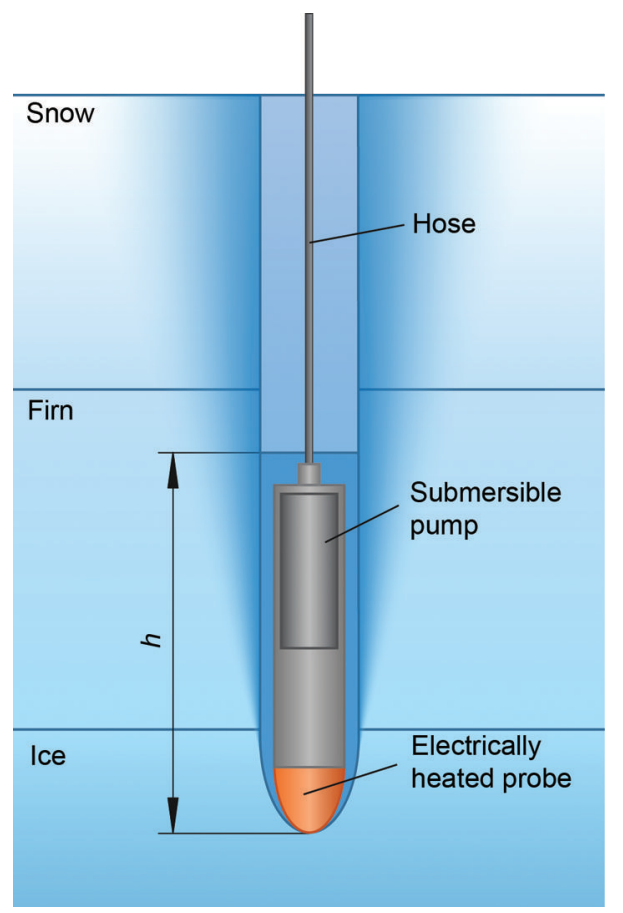

Fig. 4. Solidification of borehole wall by melting.

with a submersible pump. The water-column height $h$ has to be maintained according to predicated porosity of the drilled formation, borehole temperature and rate of penetration. In principle, it would be possible to use a thermal coring drill if core sampling is planned throughout the entire borehole.

\section{DRILLING FLUIDS}

The first drilling in ice with a fluid-filled borehole was carried out by the US Army Cold Regions Research and Engineering Laboratory (CRREL) at Camp Century, Greenland, in 1966. The method was subsequently used at Byrd Station, West Antarctica, in 1967/68 (Ueda and Garfield, 1968, 1969). The lower part of the boreholes was filled with aqueous ethylene glycol solution, and the upper part was filled with a mixture of diesel fuel (arctic blend DF-A) with trichlorethylene as a density-increasing additive ('densifier').

Over the next 50 years, dozens of intermediate and deep, fluid-filled boreholes were drilled in ice using cablesuspended electromechanical and thermal drills. Various low-temperature drilling fluids were proposed for drilling in ice, and these can be broken down into three main groups (Fig. 5): (1) two-component kerosene-based fluids with density additives, (2) alcohol compounds and (3) ester compounds.

Not all low-temperature drilling fluids qualify as the best choices from the safety, environmental and other technological standpoints (Talalay and Gundestrup, 2002). For this reason, attendees of an IPICS Workshop declared in 2004: 'The identification of a non-toxic, non-flammable, density appropriate, hydrophobic, inexpensive, environmentally friendly and readily available fluid(s) with predictable performance characteristics has become somewhat of a

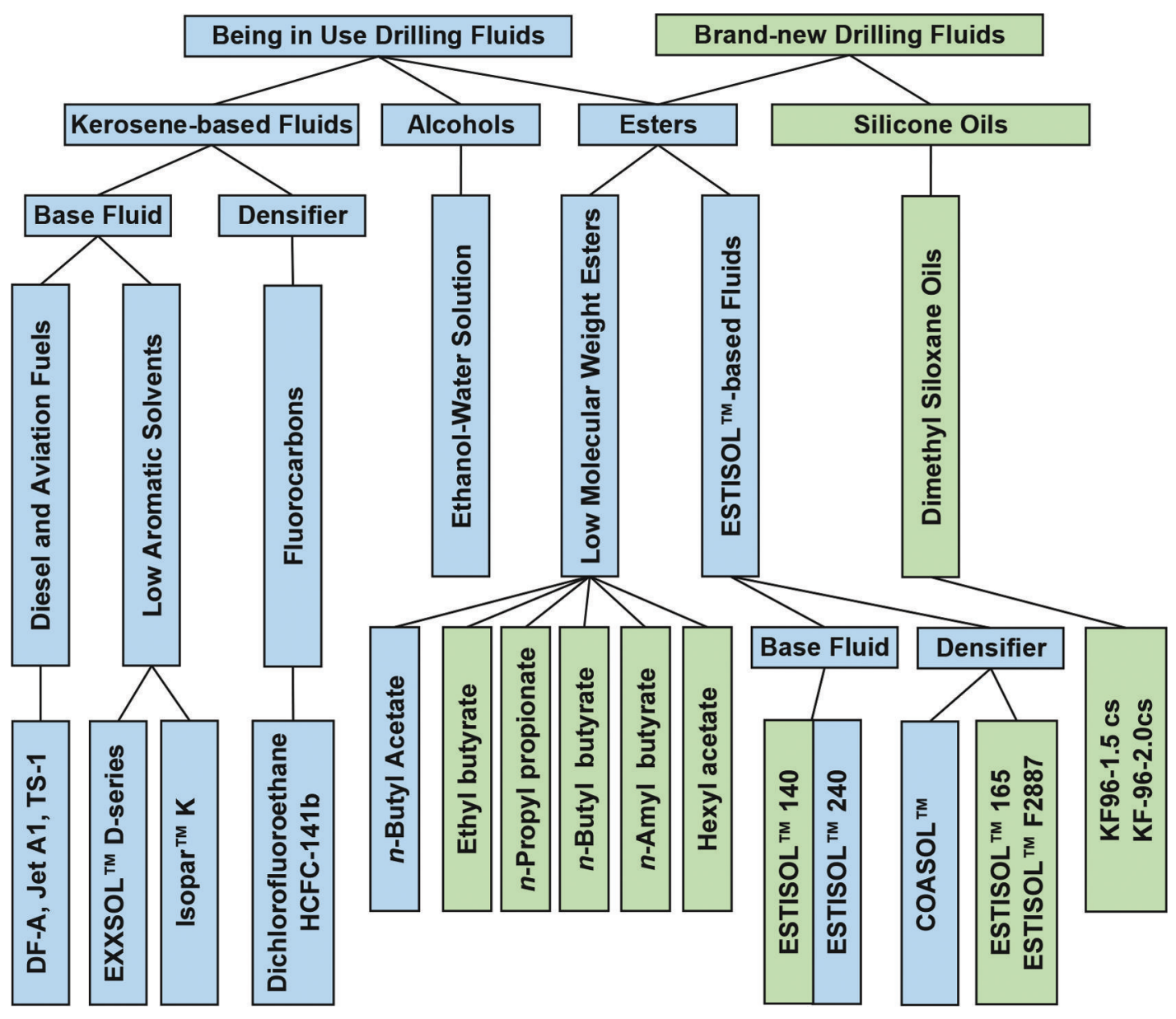

Fig. 5. Classification of being in use (blue) and brand-new (green) borehole low-temperature fluids for ice drilling. 
Holy Grail in the ice-drilling community' (IPICS, 2005). Since that time, a few new drilling fluids have been found and tested in the field (e.g. mixture of ESTISOL ${ }^{\text {TM }} 240$ and COASOL ${ }^{\mathrm{TM}}$; Sheldon and others, 2014b) but some problems (high viscosity, aggressive solubility, handling difficulties, etc.) exist with their use as well.

Most likely, the future progress of wet ice drilling will be connected with the introduction of the following new fluids:

1. Drilling fluids based on non-hazardous ESTISOL ${ }^{\mathrm{TM}} 140$ ester and used as a single liquid or two-component mixture blended in small quantities (2-6\%) with ESTISOL ${ }^{\text {TM }} 165$ or ESTISOL ${ }^{\text {TM }}$ F2887 as densifiers (Sheldon and others 2014a; Talalay and others, 2014a);

2. Low-molecular dimethyl siloxane oils that have been discussed at length previously (Talalay, 2007) and that are planned to be used in the near future in a few drilling projects (e.g. Triest and Alemany, 2014);

3. Low molecular weight esters (ethyl butyrate, n-propyl propionate, $n$-butyl butyrate, $n$-amyl butyrate, hexyl acetate) that are commonly used as artificial flavoring resembling orange juice or pineapple ( $\mathrm{Xu}$ and others, 2014);

4. Low-aromatic solvents of kerosene type mixed with fourth-generation foam-expansion agents such as DuPont $^{\mathrm{TM}}$ FEA-1100 - hydrofluoroolefin of the HFO1336mzz type (Loh and others, 2009).

The properties of the brand-new drilling fluids for ice-core drilling are summarized in Table 1. All types of potential fluids have individual advantages and disadvantages. The best and final choice of drilling fluid requires consideration of the possibilities and the plausible solutions to the aforementioned problems.

\section{ELIMINATION OF STICKING DRILLS}

Drill sticking is the most severe drilling problem that can occur, because of borehole instability or accumulation of cuttings. The selection of adequate parameters for the

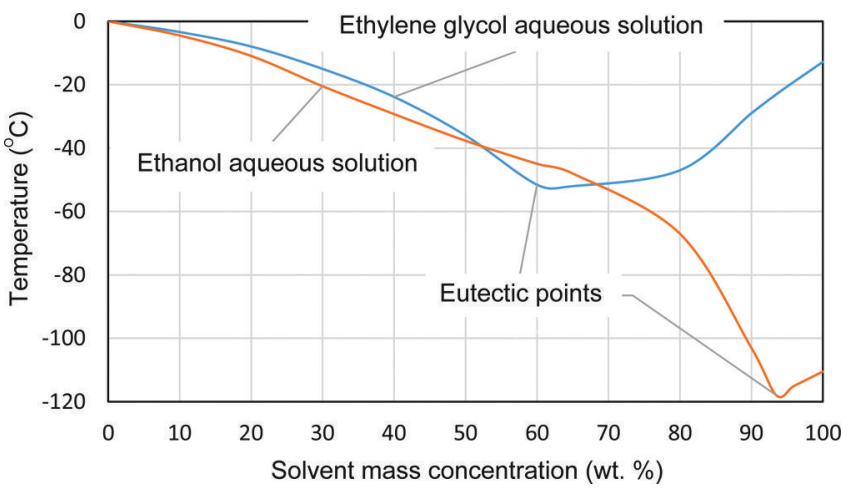

Fig. 6. Melting/freezing points of alcohol aqueous solutions vs solvent concentration (Weast, 1975; Flick, 1991).

material removal system is the main method of minimizing the sticking risk of all drill systems. Borehole instability problems are common for 'dry' drilling or under-balanced wet drilling when the hydrostatic pressure of the fluid column is not sufficient to prevent borehole closure (Talalay and others, 2014b).

Despite the success in ice-drilling technology, there remain examples of deep coring accidents not only in socalled warm ice (which has temperatures near the pressuremelting point) but also in temperate and cold ice (Gundestrup and others, 2002). Effective accident elimination is possible by dissolving the ice around the sticking drill by delivering an ice-active solvent to this area (e.g. ethylene glycol or its aqueous solution).

Ethylene glycol is a polyhydric alcohol usually used as an antifreeze agent and solvent. Ethylene glycol blends with water at any concentration. The freezing point of the aqueous solution of ethylene glycol depends on the concentration of the solvent (Fig. 6). At first, the freezing point of the aqueous solution decreases with the concentration of solvent and has a minimum (eutectic point) of $-52{ }^{\circ} \mathrm{C}$ at a concentration of $65 \mathrm{wt} \%$ (Weast, 1975). The freezing point then increases to $-12.6^{\circ} \mathrm{C}$ for pure ethylene glycol. The equilibrium concentration $C_{\mathrm{E}}$ of glycol aqueous

Table 1. Brand-new borehole fluids for ice drilling

\begin{tabular}{|c|c|c|}
\hline Type of drilling fluid & Advantages & Disadvantages \\
\hline ESTISOL ${ }^{\text {TM }}$ 140-based drilling fluids & $\begin{array}{l}\text { 1. Relatively non-toxic and environmentally friendly } \\
\text { 2. Good density properties } \\
\text { 3. Hydrophobic } \\
\text { 4. Rather cheap (US\$3.8 } \mathrm{kg}^{-1} \text { ) } \\
\text { 5. Tested in real boreholes in Greenland (NEEM) and } \\
\text { Antarctica (Aurora Basin) }\end{array}$ & $\begin{array}{l}\text { 1. High viscosity at low temperatures }\left(25.6 \mathrm{~mm}^{2} \mathrm{~s}^{-1}\right. \\
\left.\text { at }-50^{\circ} \mathrm{C}\right)\end{array}$ \\
\hline $\begin{array}{l}\text { Low-molecular dimethyl siloxane } \\
\text { oils }\end{array}$ & $\begin{array}{l}\text { 1. Non-toxic and environmentally friendly } \\
\text { 2. Good density-viscosity properties } \\
\text { 3. Hydrophobic and essentially inert substance }\end{array}$ & $\begin{array}{l}\text { 1. Never been used in ice-drilling projects } \\
\text { 2. Expensive }\left(\mathrm{US} \$ 8-10 \mathrm{~kg}^{-1}\right) \\
\text { 3. Low rate of vaporization }\end{array}$ \\
\hline Low molecular weight esters & $\begin{array}{l}\text { 1. Relatively non-toxic and environmentally friendly } \\
\text { 2. Good density-viscosity properties } \\
\text { 3. Hydrophobic } \\
\text { 4. Intermixable }\end{array}$ & $\begin{array}{l}\text { 1. Never been used in ice-drilling projects } \\
\text { 2. Moderately expensive }\left(U S \$ \sim 6 \mathrm{~kg}^{-1}\right) \\
\text { 3. Strong fruit-like odor } \\
\text { 4. Need to continue research on compatibility with } \\
\text { drill components, influence on ice chips, etc. }\end{array}$ \\
\hline
\end{tabular}


Table 2. Proposed parameters of ethylene glycol aqueous solution to recover sticking in the past drills

\begin{tabular}{|c|c|c|c|c|c|c|}
\hline \multirow[t]{2}{*}{$\begin{array}{l}\text { Drilling site } \\
\text { (year) }\end{array}$} & $\begin{array}{l}\text { Accident } \\
\text { depth }\end{array}$ & $\begin{array}{c}\text { Expected } \\
\text { temperature near } \\
\text { sticking drill }\end{array}$ & $\begin{array}{c}\text { Equilibrium concentration } \\
C_{E} \text { of glycol aqueous } \\
\text { solution at temperature } \\
\text { near sticking drill }\end{array}$ & $\begin{array}{l}\text { Proposed melting/ } \\
\text { freezing point of } \\
\text { ethylene glycol } \\
\text { aqueous solution }\end{array}$ & $\begin{array}{c}\text { Proposed } \\
\text { concentration } C_{G} \\
\text { of ethylene glycol }\end{array}$ & $\begin{array}{c}\text { Proposed frozen pills } \\
\text { mass of ethylene glycol } \\
\text { aqueous solution }\end{array}$ \\
\hline & $\mathrm{m}$ & ${ }^{\circ} \mathrm{C}$ & wt. $\%$ & ${ }^{\circ} \mathrm{C}$ & wt. \% & $\mathrm{kg}$ \\
\hline Vostok (1991) & 2259 & -32.2 & 46.9 & -38 & 85.1 & $10.3-25.9$ \\
\hline Dome F (1996) & 2250 & -21.0 & 37.8 & -28 & 90.1 & $6.7-16.7$ \\
\hline NGRIP-1 (1997) & 1371 & -31.7 & 46.5 & -38 & 85.1 & $10.2-25.6$ \\
\hline Dome C-1 (1999) & 786 & -47.8 & 56.9 & -52 & 65.0 & $17.5-43.6$ \\
\hline
\end{tabular}

solution is considered as concentration of the solvent at the freezing point $t\left({ }^{\circ} \mathrm{C}\right)$, and in the range $0-60 \mathrm{wt} . \%$ it can be estimated at

$$
C_{\mathrm{E}}=-4.87 \times 10^{-4} t^{3}-0.0554 t^{2}-2.71 t+0.794,
$$

while in the range $80-100$ wt.\% it is linearly dependent on the temperature:

$$
C_{\mathrm{E}}=0.581 t+107.1 \text {. }
$$

Ethylene glycol is reactive to ice even at subzero temperatures. The rate of the ice weight loss in ethylene glycol and its aqueous solution is quite rapid and depends on the temperature and on the solution concentration. Experimental tests demonstrated that an ice cube, being in contact with pure ethylene glycol with a temperature of $-11^{\circ} \mathrm{C}$ for 1.75 hours, lost its mass at an average rate of $12.5 \mathrm{~g} \mathrm{~h}^{-1}$. Ice dissolves up to the equilibrium concentration of the solvent at a given temperature.

Delivery of the ethylene glycol to the sticking drill with the bailer is impossible because, at the time of the accident, the armored cable is located in the hole and obstructs further tripping. Delivering solvent by gravity segregation has been recommended, as the density of pure ethylene glycol and its aqueous solution (1000-1138 $\mathrm{kg} \mathrm{m}^{-3}$ depending on temperature and concentration) is higher than the drilling fluid density, which is usually in the range 920$940 \mathrm{~kg} \mathrm{~m}^{-3}$. Unfortunately, accident elimination work in the EPICA Dome C-1 (Antarctica) borehole in 1999 and NGRIP-2 (Greenland) borehole in 2000 showed that filling the hole with an aqueous solution of ethylene glycol from the surface is not effective. This is due to the fact that, on the way to the sticking drill, the glycol dissolved borehole walls and reached the target depth almost fully diluted.

The measured temperature in most of the boreholes on the Antarctic ice sheet (Vostok, Dome C, Base Kohnen, Dome F, South Pole and other sites) is monotonously increasing with depth (Cuffey and Paterson, 2010; personal communications from L. Augustin, F. Wilhelms and H. Motoyama, 2011). The central Greenland sites (GISP2 and NGRIP) and Byrd Station exhibit nearly isothermal upper layers, but in the lower parts temperature increases almost with the same gradient as at the other sites.

Accounting for temperature distribution inside the ice sheets, Gundestrup and others (2002) offered to drop the frozen ethylene glycol into the accident borehole. The melting point of this solvent is lower than the temperature near the sticking drill and higher than that in the upper part of the hole. According to the time measurements after glycol pills drop into the NGRIP-2 borehole and till temperature increases in the electronic chamber of the stuck drill (which indicates that glycol is in place and starts to work), the falling speed of the frozen glycol pills was estimated to be $\geq 0.2 \mathrm{~m} \mathrm{~s}^{-1}$. Even though the temperature in some parts of the hole would be higher than the melting point of the solvent, there is insufficient time for it to melt down. This means that the glycol would stay frozen until it reaches the accident depth and arrives essentially undiluted at the top of the drill. This method was proven in the field many times to recover sticking drills in the 'warm' ice of the Antarctic and Greenland ice sheets. In most cases, dropping 2-5 kg of the frozen glycol pills was sufficient to release the sticking drill within 7-19 hours after dumping.

We propose that, to recover drills sticking in temperate and cold ice, it is best to use frozen glycol aqueous solutions. Once the temperature of the ice near the sticking drill is known, the equilibrium concentration of ethylene glycol can be calculated. The expected melting/freezing point of ethylene glycol aqueous solution should be lower by $5-7^{\circ} \mathrm{C}$ than the temperature near the sticking drill, then the amount of solvent $m_{\mathrm{G}}$ needed to dissolve the ice with mass $m_{1}$ can be estimated:

$$
m_{\mathrm{G}}=\frac{C_{\mathrm{E}} m_{\mathrm{I}}}{0.01 C_{\mathrm{G}}\left(100-C_{\mathrm{E}}\right)},
$$

where $C_{G}(w t . \%)$ is the mass concentration of the solvent planned to be used for drill recovery.

In the 1990s, four heavy accidents occurred at the Vostok, Dome F, Dome C-1 and NGRIP-1 holes (Table 2). In all cases, the maximal power of the winch motors could not pull out the sticking drills and further drillings in these holes were terminated (at Vostok the cable was broken from the cable termination, and the hole was deviated). Although the reasons for sticking drills vary and are sometimes unknown, the use of frozen glycol pellets could present a good opportunity to eliminate accidents. The concentration and recommended quantity of the solvent to recover these sticking drills has been estimated. Based on field experience, the ice mass to be dissolved is $\sim 10-25 \mathrm{~kg}$.

The freezing process of glycol-water solution occurs slowly and the solution can remain liquid in supercooling condition for a long time. Aqueous solution begins to freeze when the temperature drops to the melting/freezing point, but, at this temperature, only ice crystals and crusts are precipitated out. Because the glycol content in the remaining liquid increases, its final crystallization requires further temperature reduction. In order to avoid freezing-out of water from the solution, the freezing process should be as fast as possible and the applied temperature must be much 
lower than the melting/freezing point of the solution. To prepare frozen glycol pills in the field, the freezer must be capable of cooling the solution to ultra-low temperatures, preferably down to $-80^{\circ} \mathrm{C}$. Experiments showed that adding a few seed glycol crystals into supercooled antifreeze could dramatically speed up the freezing process.

Ethylene glycol is a very toxic material, especially upon inhalation (OSHA PEL: 50 ppm). It is also a skin, eye and mucous membrane irritant and therefore needs to be safely handled using very strong precautions.

To eliminate sticking drills in very cold ice (e.g. for the Dome $\mathrm{C}$ case) where the difference between hole temperature and the eutectic point of aqueous ethylene glycol solution is very small, it would be possible to use frozen pills made from aqueous ethanol solution. The eutectic point of aqueous ethanol solution $\left(-118^{\circ} \mathrm{C}\right)$ is much lower (Fig. 6), and it would be advantageous to use $80 \mathrm{wt} . \%$ solution that freezes at $-67^{\circ} \mathrm{C}$. As ethanol aqueous solution is lighter than drilling fluid, a small amount of weighting agent (e.g. bromoform) should be added before freezing. It must be noted that bromine-containing reagents are typically toxic by inhalation, ingestion and dermal absorption. Therefore, the search for a non-hazardous weighting agent should be continued.

\section{IMPROVEMENT OF CORE RECOVERY}

\subsection{Core quality in the brittle-ice zone}

As the object of core drilling is to obtain samples for interpretation and testing, it is essential to obtain as close to $100 \%$ core recovery as possible. Generally, core quality in the fluid-field boreholes is quite good and usually the core is recovered in one or several pieces. Problems with core quality are encountered in brittle ice, the zone of extremely fragile ice typically encountered in the Antarctic and Greenland ice sheets beginning several hundred meters below the ice surface and extending to depths of 1000$1500 \mathrm{~m}$ (Neff, 2014). In the brittle interval, the internal gas pressure in the bubbles creates tensile stresses in the vicinity of the bubbles that exceed the ice's strength. The phenomenological result of these stresses is a marked tendency for the ice to crack and break (with very little provocation) both during and after drilling. In extreme cases where the drill itself adds additional stresses to the ice, the recovered ice sample consists of severely cracked and broken pieces.

Experiences from the Dome F, EPICA-DML and some other drilling projects indicate that a well-tuned drill with sufficient fluid circulation and the minimization of thermal or mechanical shock during drilling, handling and storage can significantly improve core quality in the brittle zone (Wilhelms and others, 2004). In principle, it would be possible to produce good-quality core through the brittle-ice zone using a pressure core barrel that allows for core recovery from a borehole under true bottom hole pressure. Such tools are currently used to obtain gas content from oil, coal and gas hydrate formations (e.g. Kubo and others, 2014). We should point out that this technique is quite complicated, expensive and requires special facilities on the surface to retrieve core from the core barrel.

To handle, transport and store the core recovered from the brittle-ice zone without inducing additional damage, the tight-fitting liner tube can be used inside the core barrel (Fig. 7). In conventional drilling, such liners are used to

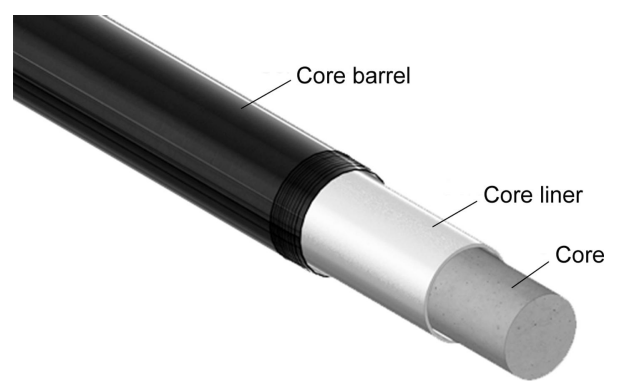

Fig. 7. Core barrel with core-liner.

improve the quality of the core recovered in unconsolidated or fractured formations (e.g. coal, water-bearing sediments, or gas shale). Liners may be made of PVC and ABS plastic, fiberglass, aluminum, or brass with a wall thickness of 1-3 $\mathrm{mm}$. When the core bit is removed, the core-filled liner can simply be pulled out by hand or by using a core-liner extrusion pump-out assembly. The disadvantages of core barrel liners are that they require a slightly decreased core diameter, resulting in an increased volume of cuttings, and that it is difficult to remove the drilling fluid during core processing while the core is inside the liner.

\subsection{Side-wall drilling}

In fact, the successful deployment of the DISC/replicate coring drill partially solved the problem of replicate core drilling. This drill is able to take $108 \mathrm{~mm}$ diameter replicate ice cores from the larger-diameter parent borehole, and during the 2012/13 WAIS Divide field Antarctic season the system produced five azimuth and depth-controlled deviations at four target depth levels (Shturmakov and others, 2014). Unfortunately, the system is extremely complicated, expensive and can work only from the DISC parent hole (170 mm).

A less expensive and simpler solution involves using wireline side-wall coring systems which were developed in conventional drilling to obtain core samples from borehole walls after they have been drilled. Of course, these systems are designed to acquire a smaller core sample than is possible with the DISC/replicate coring drill. Nevertheless, retrieved samples are suitable for studies of tephra layers or other layers of specific interest. Wireline side-wall coring systems are available but need to be modified for coring in ice holes by redesigning the drill head and adapting them to low-temperature application.

The side-wall coring system can be precisely positioned in the zone of interest. To this end, it can be equipped with an optical televiewer or laser dust logger that, combined with core inspection from the parent hole, will fit the sample into an existing stratigraphy. The side-wall coring system includes the short horizontal core barrel with a cutting bit that penetrates the wall and is then retracted into the tool's body where the core sample is deposited (Fig. 8). The tool is moved to a new location after depositing each sample. The standard configuration of the rotary mechanical side-wall coring tool recovers up to 50 side-wall core samples. Each sample is isolated for positive identification, and a summary output at the surface lists all samples with the exact depth and time at which each was recorded. The diameter and length of the core sample taken during one trip depend on the size of the parent hole. Typically, the diameter of the core side-wall samples is $\sim 24 \mathrm{~mm}$ and length $\sim 44 \mathrm{~mm}$. 


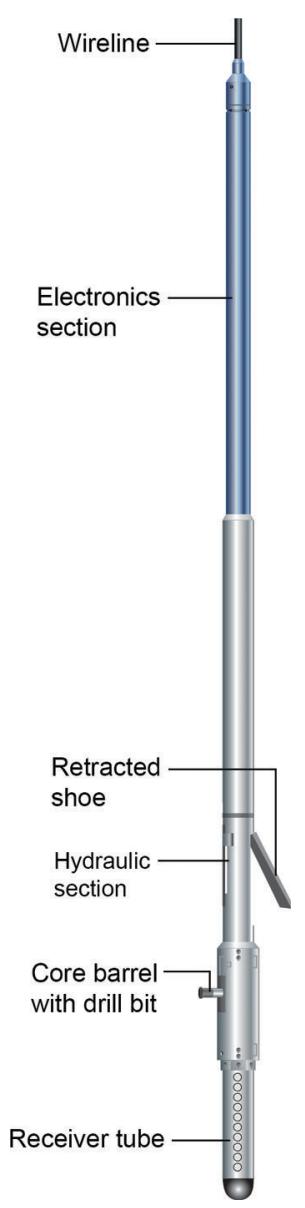

Fig. 8. Schlumberger Ltd mechanical side-wall coring tool (Schlumberger, 2004).

\subsection{Oriented core}

Even if the azimuth and declination of the hole are known, the extraction process rotates the core randomly so that once the core is laid out on the processing table its original orientation is lost. In that case, the core cannot provide information about the three-dimensional structure of the ice sheet. The most common orientation method in exploration drilling is the use of a heavy metal spear that is lowered down the hole on a wireline and that hits the bottom of the hole, producing a mark on the next piece of rock to be cored. Unfortunately, these instruments only work in holes with declinations $>15^{\circ}$ from vertical.

The problem of sampling oriented core with electromechanical and thermal cable-suspended drills, which include a downhole inclinometer, can be solved easily. At the moment of core breaking, the inclination and azimuth of the drill are recorded, indicating that the position in space of the pressure chamber is known. An electromechanical drill has graduated rims between the upper non-rotated and the lower rotated parts or rotary encoder on the output shaft that converts the angular position of the core barrel to an analog or digital code. These measures connect the relative positions of non-rotated and rotated drill parts. In thermal drills, this is not necessary as there are no rotated sections. While tripping, the core being clamped by core catchers should be reliably fixed in the core barrel. To avoid the effect of core turning during lifting, the asymmetric 'dog-leg'-type core catchers or core catchers with different shape/width can be used to cut a 'barcode' into the core surface in the event of the core breaking. When both hole and core orientations are known, features within the core can be accurately oriented.

\section{AUTOMATED DRILLING SYSTEMS}

Automation of oil-well construction, blasting and exploration drilling is rapidly growing. Automated drilling systems allow the most routine drilling operations to be performed in unmanned mode. This is of particular importance in the high-altitude, cold, remote conditions of the polar regions, where a human being's psychophysical state is greatly changed. The short-run prospect is that automated icedrilling systems will have to be integrated into the icedrilling process to improve operational safety, accelerate cycle time and minimize waste.

Over the past few years, attempts have been made to develop automated tools as part of ice-drilling systems. For example, an automatic control system for drill-lowering speed in a wet hole was designed at the St Petersburg Mining Institute, Russia. This system releases drillers from tiresome handheld operation of manual winch control which ensures that the electromechanical cable is taut. Otherwise, the cable slackens and kinks develop. If the armour is weakened, the cable might break or communication with the drill could be lost. The general rule stands that the cable-lowering speed should be equated with the drill's free speed in the fluid, which may vary because of drillingfluid viscosity variations and borehole irregularities. The automatic control system allows for automatic adjustment to the winch revolutions, due to the signal incoming from the load sensor. In 1991, the automatic control system of the drill's lowering speed was tested at Vostok station, and facilitated not only the driller's work but also reduced the time expended on the lowering operations by nearly $10 \%$ (personal communication from A.V. Krasilev, 1992).

When the drill is lifted out of the hole, the total weight of the retracted cable changes. It is also advisable to use automatic control of the winch rotation speed with a selfadjustable system. In both cases - lowering and hoisting the maximum speed has to be limited according to (1) the maximum speed permitted by safety regulations (e.g., according to the Russian 'Safety Regulation for Exploration' (Federal'noye Agenstvo po Nedropl'zovaniyu, 2005) it is not allowed to maintain tripping with rates more than $1.5 \mathrm{~m} \mathrm{~s}^{-1}$ ) and (2) the maximal power of the winch driving motor.

Automation can also be used for (1) preparation of the drilling fluid mixture according to the required density, (2) filling the borehole with drilling fluid in accordance with prescribed top fluid limits and (3) ice-cuttings processing including drying/melting/packing, etc.

In relation to automated systems, it is pertinent to consider ice-core drilling simulators that can artificially recreate tripping and drilling processes. This would provide a very useful tool for student and driller training in basic drilling concepts and allows trainees to be exposed to a broad range of scenarios from routine operations to abnormal challenges and emergencies with accident potential.

\section{RAPID-ACCESS ICE DRILLS FOR SUBGLACIAL BEDROCK DRILLING}

The rapid-access ice drill (RAID) system is capable of quickly accessing ice-sheet beds down to 3000-3500 m of ice and collecting ice intervals of interest and a few tens of 
meters of core from the subglacial material. Drilling to these depths would be completed within $\sim 2-3$ weeks so that several holes could be produced in a single summer field season. The RAID system has been an elusive objective for glaciologists for more than a decade. Renewed interest comes from geologists seeking subglacial bedrock samples to, for example, validate geotectonic and paleogeographic reconstructions. The approaches to RAID systems can be divided into three groups: (1) conventional drilling technology used in oil wells or the mineral-exploration industry, (2) hot-water drill systems with a subsystem for subglacial sampling and (3) unconventional drilling systems.

\subsection{Conventional drilling technology}

The use of coiled tubing drill systems for fast access to the subglacial environment and bedrock coring has been proposed by Clow and Koci (2002). Coiled tubing systems are widely used in oil and gas wells for workover, cleanouts, acid spotting, fishing, drilling and logging. This system, however, will require major development for adaptation to polar region explorations. The minimum operating temperature for commercial composite tubing is currently $-40^{\circ} \mathrm{C}$. At lower temperatures, the tubing liner becomes too brittle. The long-term performance of other subsurface components (e.g. hydraulic motors, circulation sub-assemblies, coildriven unit) at very low temperatures and repeated drilling cycles should be evaluated; component modifications likely are required. The coiled tubing itself is subject to fatigue every time it is cycled through bending. The usual lifetime of a coil is 100-200 trips, depending upon the axial and pressure loading.

The concept of the recently proposed rapid-access drilling system with minimal resources and logistics support, RADIX, is also based on a coiled drilling system (Schwander and others, 2014). It is intended to drill a 'pinhole' with smallest diameter using a hydraulic downhole motor suspended on a small hose. The practical lower limit of the borehole size is assigned by the flow resistance through the hydraulic tubing and is in the range $20-25 \mathrm{~mm}$. The expected rate of penetration of $\sim 10 \mathrm{~mm} \mathrm{~s}^{-1}$ would result in $<4$ days of continuous drilling for a $3000 \mathrm{~m}$ hole. The hole can be used for temperature and other downhole measurements. The drilled ice chips and/or core samples from specific depths will be available for analysis. The main problem of the system is the feasibility of the removal system because ice cuttings transport is questionable in the small space between the hose and the borehole wall.

Gerasimoff (2012) suggested the RAID system be adapted from wireline diamond-drilling technology. During coring, a tubular cutter head with sharp metal teeth cuts an annular groove and the core enters an inner core barrel, where it is latched immediately behind the head in the same manner as normal rock-coring operations. During boring (only boring, not coring), the core barrel is removed using the wireline retrieval device and replaced by a novel, custom insert of very similar geometry. Rather than residing entirely within the outer core barrel and entirely behind the cutter head, a portion of this innovative custom insert protrudes through the cutter head where the core normally enters and is fitted there with cutter teeth. In this way, the portion of the ice normally cored is reduced to chips and flushed away by the fluid. The current design of the US drilling community for RAID is based on a modification of a standard rotary diamond-coring rig as it was used in the mineral exploration industry, operated in a flooded reverse-circulation mode with composite drill rods (Goodge and Severinghaus, 2014).

To use commercial drill rigs in polar conditions, many components (e.g. hydraulic system, fluid-processing system, etc.) will need to be redesigned as they are not able to operate at low temperatures (Talalay, 2013). Commercial drill rigs operate as outdoor machines or use tents or primitive shelters that are inadequate at extremely low temperatures and in storm winds in Antarctica. In addition, commercial drill rigs are still very heavy and powerconsuming. They require a large logistical load to move and support, so their use in Antarctica is not only disadvantageous but, in some cases, impossible.

A critical area for conventional drilling system development is to discover a way to efficiently separate the chips from the drilling fluid once chips reach the surface. This process may ultimately limit how quickly the system can penetrate ice. The separation process must be fast enough for the drilling fluid to be pumped back down the hole. Chip separation for conventional drill rigs is accomplished using a shaker table and high-speed centrifuge. These systems have never been used for ice and will need serious modification to work properly in a cold polar environment.

It is expected that the RAID systems based on conventional drilling technologies are not clean enough for discovery of subglacial lakes, which is why drilling can only be performed in frozen-bed conditions to avoid contaminating the subglacial hydrologic environment.

\subsection{Hot-water drill systems}

Hot-water drill systems have been well-known access approaches since the 1980s (e.g. Engelhardt and Determann, 1987; Koci, 1989) and can be considered the fastest type of RAIDs. On the way down, a hot-water ice-coring drill with a ring of water jets as the coring head can be used occasionally to obtain ice cores at targeted depths from hotwater drilled holes (Engelhardt and others, 2000). The main hot-water drill drills to a targeted depth, the drill nozzle is bought back to the surface, the hot water corer attached to the end of the hose and the corer deployed. The technique was refined to the point where $1-2 \mathrm{~m}$ long cores of $\sim 100 \mathrm{~mm}$ diameter could be reliably retrieved.

In principle, it would be possible to collect subglacial material samples by hot-water drilling. During the 1987/88 field season, the hot-water drill remained at the bottom of a $480 \mathrm{~m}$ deep hole for $\sim 1$ hour before being raised to the surface (Bindschadler and others, 1988). When the drill returned to the surface, it was coated with a thick mud layer, and a $5 \mathrm{~cm}$ diameter rock as well as a $4 \mathrm{~cm}$ long mudclast were lodged in the caliper arms. In addition, $\sim 1000 \mathrm{~cm}^{3}$ of sediment material was spread over the drill stem, filling most of the ledges and holes. Though penetration into subglacial rock sediments by hot-water drilling technologies is technically possible, we do not include them as an option for subglacial bedrock drilling, because sampling is not as deep as required and sediments cannot be retrieved with intact stratigraphy.

For ice and subglacial bedrock core sampling with a hotwater drill system, Das and others (1992) suggested installing a positive displacement motor (PDM) that rotates the core barrel instead of the hot-water nozzle. A PDM converts the hydraulic pressure of hot-water flow into rotation and torque, and hot water itself will be used to melt ice chips created during the drilling process. Thus, the 
drill requires no chip storage area. The core is expected to be $200-300 \mathrm{~mm}$ in diameter and up to $10 \mathrm{~m}$ long. The ability to use warm water as a chip transport/melting medium has been demonstrated at the University of Alaska (USA) test hole (Koci, 1994). A $1 \mathrm{~m}$ long $15 \mathrm{~cm}$ diameter core was retrieved successfully despite the presence of rocks, sand, leaves, and cracks in the ice. The bedrock core diameter will be smaller due to increased power requirements, and chip storage will be required for rock cuttings.

Another subglacial sampling method includes two drilling systems: a hot-water drill for fast-access drilling and a mechanical drill rig that should change the hot-water drill system when approaching the ice-sheet base. Drilling operations at Black Rapids Glacier, Alaska, showed that subglacial core sampling is technically possible by a commercial wireline drill rig from the holes pre-drilled by the hot-water drill system (Truffer and others, 1999). Nevertheless, there were substantial difficulties in sampling subglacial till. Penetration itself was difficult because of clogging of the core barrel entrance with rock fragments, which then prevented entry of any further material. The other problem was caused by water circulation. The stream of water caused the fine sediments, sand and even gravel to be washed away from the core barrel. Chances of core recovery could not exceed $25-30 \%$. To avoid such problems, in principle, it would be possible to replace water in the hole with low-temperature drilling fluid. However, it must be kept in mind that hot-water drill systems produce rather large-diameter holes, and the amount of drilling fluid required $\left(100-400 \mathrm{~m}^{3}\right.$ ) makes this method impracticable. Moreover, it requires two independently heavy and powerconsuming drilling systems: one for pre-drilling in ice and another for subglacial sampling.

Mulvaney and others (2013) suggested gaining access to the ice-sheet bed by using hot-water drilling technology and by sampling bedrock with an electromechanical drill suspended on armoured cable. The drill can be deployed in a borehole of $\sim 150 \mathrm{~mm}$ minimum diameter and can counter the torque from the drill head by gripping the borehole wall, which is likely to vary in diameter particularly near the base. Rock chips and flour from the drill head can be removed using recirculating water pumps and filters. This approach also requires two independently heavy and power-consuming drilling systems.

Thus, hot-water access drilling combined with mechanical subglacial sampling has such significant unsolved problems that it remains under discussion for Antarctic inland application.

\subsection{Unconventional drilling systems}

In trying to find methods to drill faster and safely, the new unconventional heating methods (laser, plasma, e-beam) should be taken into consideration. Perhaps the most promising unconventional drilling system is laser drilling. Lasers emit light through a process of optical amplification based on the stimulated emission of electromagnetic radiation and are widely used in industry for cutting different materials. Proposals for laser drilling in rocks go back almost five decades, but in the past, lasers have been limited by their relatively low power levels and poor efficiency. During the past decade, intensive research has been carried out into the development of a system that can transmit high-power lasers over long distances via fiber-optic cables. Foro Energy (Littleton, CO/Houston, TX, USA) has demonstrated that
$20 \mathrm{~kW}$ of laser power delivered through a $1500 \mathrm{~m}$ long optical fiber can efficiently drill through hard rock (Foro Energy, 2013).

Another example of laser energy use is a self-contained intelligent ice hot-water penetrator, VALKYRIE (Very-deep Autonomous Laser-powered Kilowatt-class Yo-yoing Robotic Ice Explorer), capable of delivering science payloads through ice caps to subglacial lakes (Siegel and others, 2013). Power to the vehicle is delivered through a fiberoptic cable to the downhole optics package, and the beam dump converts the photons to heat. Melted water in front of the vehicle is drawn through a heat exchanger on the sides of the beam dump, and the heated water is sent to pumps that supply hot-water jets at the head of the vehicle. Testing of a power transmission system at Stone Aerospace Inc. (Austin, TX, USA) between 2010 and 2013 has already demonstrated high-power optical energy transfer over relevant distances as well as the feasibility of a vehicledeployed optical waveguide.

The unconventional thermal drills can drill at a high rate but require 10-20 times more energy for ice disintegration than conventional rotary rigs. Intensive support is required in the research phase of these technologies.

\section{ACKNOWLEDGEMENTS}

This paper describes the research done under support of the National Science Foundation of China (Projects No. 41276189 and No. 41327804), Geological Survey of China (Project No. 3R212W324424) and Ministry of Land and Resources of China (Project No. 201311041). I thank M. Sysoev (Jilin University, Changchun, China) for figure preparation, and Mark Twickler and Molly Wade (University of New Hampshire, USA) for help in editing the paper. I also thank J.P. Steffensen (University of Copenhagen, Denmark) and F. Wilhelms (Alfred Wegener Institute, Germany) for helpful suggestions.

\section{REFERENCES}

Bentley CR and 12 others (2009) Ice drilling and coring. In BarCohen $\mathrm{Y}$ and Zacny $\mathrm{K}$ eds. Drilling in extreme environments: penetration and sampling on Earth and other planets. WileyVCH, Weinheim, 221-308

Bindschadler RA, Koci B and Iken A (1988) Drilling on Crary Ice Rise, Antarctica. Antarct. J. US, 23(5), 60-62

Clarke GKC (1987) A short history of scientific investigations on glaciers. J. Glaciol., Special Issue, 4-24

Clow GD and Koci B (2002) A fast mechanical-access drill for polar glaciology, paleoclimatology, geology, tectonics and biology. Mem. Natl Inst. Polar Res., Special Issue 56, 5-37

Cuffey KM and Paterson WSB (2010) The physics of glaciers, 4th edn. Butterworth-Heinemann, Oxford

Das DK, Koci BR and Kelley JJ (1992) Development of a thermal mechanical drill for sampling ice and rock from great depths. Tunnel. Undergr. Space Technol., 7(4), 377-382 (doi: 10.1016/ 0886-7798(92)90067-R)

Duphil R, Possenti P and Piard L (2014) A new leak-tight borehole casing at Dome Concordia station, Antarctica, for the SUBGLACIOR project. Ann. Glaciol., 55(68) (doi: 10.3189/ 2014AoG68A022) (see paper in this issue)

Engelhardt H and Determann J (1987) Borehole evidence for a thick layer of basal ice in the central Ronne Ice Shelf. Nature, 327(6120), 318-319 (doi: 10.1038/327318a0) 
Engelhardt H, Kamb B and Bolsey R (2000) A hot-water icecoring drill. J. Glaciol., 46(153), 341-345 (doi: 10.3189/ 172756500781832873)

Federal'noye Agenstvo po Nedropl'zovaniyu (2005) Pravila bezopastnosti pri geologorazvedochnikh rabotakh PB 08-37-2005 [Safety regulation for exploration 2005]. Federal'noye Agenstvo po Nedropl'zovaniyu [Federal Agency for Subsurface Resources Management], Moscow [in Russian]

Flick EW (1991) Industrial solvents handbook. Noyes Publications, Park Ridge, NJ

Foro Energy (2013) Drilling: penetrating ultrahard rock with high power lasers. http://www.foroenergy.com/applications\#tabapplications-drilling

Gerasimoff MD (2012) Rapid access ice drill. (Prospectus) Ice Drilling Design and Operations (IDDO), University of WisconsinMadison, WI http://www.icedrill.org/Documents/Download. pm?DOCUMENT_ID=765

Gillet F, Donnou D, Girard C, Manouvrier A, Rado C and Ricou G (1984) Ice core quality in electro-mechanical drilling. CRREL Spec. Rep. 84-34, 73-80

Goodge J and Severinghaus J (2014) Construction of the Rapid Access Ice Drill (RAID) begins. Ice Bits Newsl., Summer, 5-7

Gundestrup NS, Johnsen SJ, Hansen SB, Shoji H, Talalay P and Wilhelms F (2002) Sticking deep ice core drills. Why and how to recover. Mem. Natl Inst. Polar Res., Special Issue 56, 181-195

Humphrey $\mathrm{N}$ and Echelmeyer K (1990) Hot-water drilling and borehole closure in cold ice. J. Glaciol., 36(124), 287-298 (doi: 10.3189/002214390793701354)

International Partnerships in Ice Core Sciences (IPICS) (2005) Workshop Report, 13-16 March 2004, Sterling, VA, USA. http:// pages-igbp.org/download/docs/working_groups/ipics/docs/ 2004-IPICSWorkshop.pdf

Johnsen SJ, Gundestrup NS, Hansen SB, Schwander J and Rufli H (1994) The new improved version of the ISTUK ice core drill. Mem. Natl Inst. Polar Res., Special Issue 49, 9-23

Koci B (1989) A deep hot water drill system with potential for bottom sampling. In Rado C and Beaudoing D eds. Proceedings of the 3rd International Workshop on Ice Drilling Technology, 10-14 April 1988, Grenoble, France. US Ice Drilling Program Office, Hanover, NH, 137-139

Koci B (1994) The AMANDA project: drilling precise, largediameter holes using hot water. Mem. Natl Inst. Polar Res., Special Issue 49, 203-211

Koci BR and Sonderup JM (1990) Evaluation of deep ice core drilling systems. (PICO Tech. Rep. TR-90-1) Polar Ice Coring Office, University of Alaska Fairbanks, Fairbanks, AK

Kubo Y, Mizuguchi Y, Inagaki F and Yamamoto K (2014) A new hybrid pressure-coring system for the drilling vessel Chikyu. Sci. Drilling, 17, 37-43 (doi: 10.5194/sd-17-37-2014)

Kudryashov BB and 9 others (2002) Deep ice coring at Vostok Station (East Antarctica) by an electromechanical drill. Mem. Natl Inst. Polar Res., Special Issue 56, 91-102

Loh G, Creazzo JA and Robin ML (2009) White Paper on DuPont Formacel: development program update for low GWP foam expansion agent. DuPont Fluorochemicals http://www2.dupont. com/Formacel/en_US/assets/downloads/white_paper_FEA1100.pdf

Motoyama $\mathrm{H}$ and 8 others (2013) Analysis of shallow/deep ice core drilling data, and the future plan of intermediate depth drilling. In Abstracts from the 7th International Workshop on Ice Drilling Technology, 9-13 September 2013, University of Wisconsin, Madison, WI, 39 http://icedrill.org/7th-international-workshopon-ice-drilling-technology/7-ws-idt_abstract-book_FINAL.pdf

Mulvaney R, Bentley M and Makinson K (2013) CosmoDrillWAIS: proposed drilling project to recover cosmogenic isotopes from subglacial bedrock. In Abstracts from the 7th International Workshop on Ice Drilling Technology, 9-13 September 2013, University of Wisconsin, Madison, WI, $57 \mathrm{http}$ ///icedrill.org/ 7th-international-workshop-on-ice-drilling-technology/7-ws-idt_ abstract-book_FINAL.pdf
Mulvaney R, Triest J and Alemany O (2014) The James Ross Island and the Fletcher Promontory ice-core drilling projects. Ann. Glaciol., 55(68) (doi: 10.3189/2014AoG68A044) (see paper in this issue)

Neff PD (2014) A review of the brittle-ice zone in polar ice cores. Ann. Glaciol., 55(68), 72-82 (doi: 10.3189/2014AoG68A023)

Rand J (1980) 1979 Greenland Ice Sheet Program Phase 1: casing operation. CRREL Spec. Rep. 80-24

Schwander J and Rufli H (1988) Electromechanical drilling in dry holes to medium depths. In Rado C and Beaudoing D eds. Proceedings of the 3rd International Workshop on Ice Drilling Technology, 10-14 October 1988, Grenoble, France. US Ice Drilling Program, Hanover, NH, 32-37

Schwander J, Marending S, Stocker TF and Fischer H (2014) RADIX: a minimal-resources rapid-access drilling system. Ann. Glaciol., 55(68), 34-38 (doi: 10.3189/2014AoG68A015)

Schlumberger (2004) Mechanical sidewall coring tool (MSCT). http://www.slb.com/services/characterization/reservoir/wireline/ mechanical_sidewall_coring.aspx

Sheldon SG, Popp TJ, Hansen SB and Steffensen JP (2014a) Promising new borehole liquids for ice-core drilling on the East Antarctic high plateau. Ann. Glaciol., 55(68) (doi: 10.3189/ 2014AoG68A043) (see paper in this issue)

Sheldon SG, Steffensen JP, Hansen SB, Popp TJ and Johnsen SJ (2014b) The investigation and experience of using ESTISOL ${ }^{\mathrm{TM}} 240$ and $\mathrm{COASOL}^{\mathrm{TM}}$ for ice-core drilling. Ann. Glaciol., 55(68) (doi: 10.3189/2014AoG68A036) (see paper in this issue)

Shturmakov AJ, Lebar DA and Bentley CR (2014) DISC drill and replicate coring system: a new era in deep ice drilling engineering. Ann. Glaciol., 55(68) (doi: 10.3189/2014AoG68A017) (see paper in this issue)

Siegel V, Stone WC, Hogan B, LeLievre S and Flesher C (2013) Project VALKYRIE: development of a laser powered autonomous ice penetrator. In Abstracts from the 7th International Workshop on Ice Drilling Technology, 9-13 September 2013, Madison, WI, USA, $46 \mathrm{http} / / /$ icedrill.org/7th-international-workshop-onice-drilling-technology/7-ws-idt_abstract-book_FINAL.pdf

Subsea World News (2014) BAS gets improved ice core drilling winch from MacArtney. Subsea World News. http:// subseaworldnews.com/2014/05/07/bas-gets-improved-ice-coredrilling-winch-from-macartney/

Suflex Inc. (2014) Astra@601 low temperature PVC tubing. http:// www.suflex.com/Low-Temperature-PVC-Tubing.html

Talalay PG (2007) Dimethyl siloxane oils as alternative for borehole fluid. Ann. Glaciol., 47, 82-88 (doi: 10.3189/ 172756407786857785)

Talalay PG (2013) Subglacial till and bedrock drilling. Cold Reg. Sci. Technol., 86, 142-166 (doi: 10.1016/j.coldregions.2012.08.009)

Talalay PG and Gundestrup NS (2000) Resul'taty bureniya glubokikh skazhin v tsebtral'noi chasti Grenlanskogo lednikovogo pokrova [Results of deep drilling in central part of the Greenland Ice Sheet]. In Proceedings of the IV International Symposium on Drilling in Complicated Conditions, 8-12 June 1998, St Petersburg, Russia. St Petersburg State Mining Institute, St Petersburg, 37-43

Talalay PG and Gundestrup NS (2002) Hole fluids for deep ice core drilling. Mem. Natl Inst. Polar Res., Special Issue 56, 148-170

Talalay PG and Hooke RLeB (2007) Closure of deep boreholes in ice sheets: a discussion. Ann. Glaciol., 47, 125-133 (doi: 10.3189/172756407786857794)

Talalay P and 7 others (2013) Electromechanical drill with air reverse circulation. In Abstracts from the 7th International Workshop on Ice Drilling Technology, 9-13 September 2013, University of Wisconsin, Madison, WI, $66 \mathrm{http} / / /$ icedrill.org/ 7th-international-workshop-on-ice-drilling-technology/7-ws-idt_ abstract-book_FINAL.pdf

Talalay P and 6 others (2014a) Environmental considerations of low-temperature drilling fluids. Ann. Glaciol., 55(65), 31-40 (doi: 10.3189/2014AoG65A226)

Talalay PG and 6 others (2014b) Drilling fluid technology in ice sheets: hydrostatic pressure and borehole closure considerations. 
Cold Reg. Sci. Technol., 98, 47-54 (doi: 10.1016/j.coldregions. 2013.10.012)

Triest J and Alemany O (2014) Drill fluid selection for the SUBGLACIOR probe: a review of silicone oil as a drill fluid. Ann. Glaciol., 55(68) (doi: 10.3189/2014AoG68A028) (see paper in this issue)

Truffer M, Motyka RJ, Harrison WD, Echelmeyer KA, Fisk B and Tulaczyk S (1999) Subglacial drilling at Black Rapids Glacier, Alaska, U.S.A.: drilling method and sample descriptions. J. Glaciol., 45(151), 495-505

Ueda HT and Garfield DE (1968) Drilling through the Greenland ice sheet. CRREL Spec. Rep. 126

Ueda $\mathrm{H}$ and Garfield DE (1969) Core drilling through the Antarctic ice sheet. CRREL Tech. Rep. 231

Vasiliev NI and 8 others (2007) Deep drilling at Vostok Station, Antarctica: history and recent events. Ann. Glaciol., 47, 10-23 (doi: 10.3189/172756407786857776)
Wang R, Talalay P, Hu Z and Gong D (2013) Rapid ice drilling concept with air continual transporting of cuttings and cores. In Abstracts from the 7th International Workshop on Ice Drilling Technology, 9-13 September 2013, Wisconsin, MI, USA, $6 \mathrm{http}$ ///icedrill.org/7th-internationalworkshop-on-ice-drilling-technology/7-ws-idt_abstract-book FINAL.pdf

Weast RC, ed. (1975) CRC handbook of chemistry and physics, 56th edn. CRC Press, Cleveland, $\mathrm{OH}$

Wilhelms F and 7 others (2004) White paper: ice core drilling technical challenges. International Partnership in Ice Core Sciences (IPICS) http://pages-igbp.org/download/docs/working groups/ipics/white-papers/IPICS_drilling.pdf

$\mathrm{Xu} \mathrm{H}$ and 6 others (2014) Low-molecular-weight, fatty-acid esters as potential low-temperature drilling fluids for ice coring. Ann. Glaciol., 55(68) (doi: 10.3189/2014AoG68A003) (see paper in this issue) 